\title{
YLIOPISTOJEN OHJAUSJÄRJESTELMÄSTÄ
}

Valtio ohjaa yliopistoja ja niiden toimintaa jatkuvasti muuttuvan palkitsemisjärjestelmän avulla. Valtio palkitsee yliopistoja tuottavuudesta ja tehokkuudesta: mitä tuottavampi ja tehokkaampi yliopisto on, sitä runsaammalla kädellä valtio sitä rahoittaa.

Jokainen palkitsemisjärjestelmä on samalla myös rankaisujärjestelmä. Tehottomuudesta rangaistaan palkinnotta jättämisellä. Yliopistojen ohjausjärjestelmässä kysymys ei kuitenkaan ole siitä, että jokin ylimärärinen bonus jää saamatta, jos yliopisto ei ole ollut tarpeeksi tehokas. Periaatteessa yliopistojen rankaisujärjestelmä on vanha kunnon keppi-porkkana-malli, mutta kepityksen sijaan tehottomuudesta rangaistaan siinä nälkään näännyttämisellä. Tuottavuudesta ja tehokkuudesta on tullut yliopistojen olemassaolon ehto; tutkimuksesta ja opetuksesta on tullut selviytymistaistelua. Tuota tai tuhoudu, tulos tai ulos.

Joku voisi luulla, että tässä on otettu mallia yritysmaailmasta. Näin ei kuitenkaan ole. Yritysmaailmassa toimivat aivan toisenlaiset säännöt ja lainalaisuudet. Toki sielläkin tuhoudutaan ilman tulosta: siellä tuhoudutaan, jos tuotteilla ei ole kysyntää markkinoilla tai jos yrityksen arvo osakemarkkinoilla jostain muusta syystä romahtaa.

Yliopistojen kohdalla mistään tällaisesta ei ole kyse. En sano tätä sitä silmällä pitäen, että valtion pitäisi siirtyä palkitsemaan ja rankaisemaan yliopistoja siitä, mikä niiden mahdollinen markkina-arvo on tai miten paljon niiden palveluksia tosiasiassa kysytään. Tarkoituksena on vain osoittaa näiden kahden järjestelmän ero ja sitä kautta täsmentää niiden mekanismien kuvausta, joilla valtio nykyisin ohjaa yliopistojen toimintaa.
Toki yliopistojenkin tulee nykyisessä ohjausjärjestelmässä mukautua kysyntään. Tämä kysyntä ei kuitenkaan ole kysyntää markkinoilla, sillä viime kädessä yliopistojen palveluksilla on vain yksi maksava asiakas: valtio.

Valtio ei toki ole ainoa taho, joka käyttää yliopistojen tuotteita ja palveluja - eihän valtio niitä oikeastaan käytäkään vaan sen tekevät muun muassa opiskelijat. Valtio on kuitenkin ainoa taho, joka näistä tuotteista ja palveluista maksaa, ja maksajan roolissa se on määräävässä asemassa. Maksaja voi määrätä tarjonnan. Toisin kuin yritykset markkinoilla, yliopistot joutuvat mukautumaan $y$ hden tilaajaan makumieltymyksiin.

Valtio ei toki määrää yliopistojen toimintaa suoraan vaan välillisesti, nimittäin palkitsemis- ja rankaisujärjestelmänsä kautta. Palkitessaan tai rangaistessaan se kuitenkin pakottaa yliopistot toimimaan määrätyllä tavalla, sillä kuten sanottua kyseessä on selviytymispeli, ei bonusjärjestelmä.

On totta, että valtio ei - "korkeatasoisuutta" lukuun ottamatta - kovin tarkkaan sanele minkä sisältöistä opetusta tai tutkimusta yliopistojen on tuotettava. Toisaalta se kyllä sanelee varsin tarkkaan, millaisia tuotoksia opetuksesta, tutkimuksesta ja kaikesta muustakin on synnyttävä. Valtio ei enää anna rahaa opetusta varten vaan palkitsee rahallisesti opintopisteistä, maisterimääristä, tohtorimääristä, läpivirtaavuusnopeudesta ja niin edelleen. Se ei enää anna rahaa tutkimusta varten vaan palkitsee tutkimusrahoituksen hankkimisesta, pisteytetyistä julkaisuista ja niin edelleen - tai jättää palkitsematta ja tuomitsee häviämään, jos yliopisto ei näissä määrällisissä tehtävissä menesty tai tällaisia mitattavia tuotoksia saa aikaan. 
Kysynnän monopoli ei kuitenkaan ole ainoa asia, joka erottaa yliopistomaailman yritysmaailmasta - onhan sitä paitsi yritysmaailmassakin tapauksia, joissa tuotteelle on olemassa vain yksi ostaja. Toinen on laatu. Yliopistojen nykyisen ohjausjärjestelmän suurin ongelma on nimenomaan siinä, että se lähes täysin ohittaa kysymyksen laadusta. Yrityksen tuotteiden kysyntä määräytyy pitkälle niiden laadun mukaan (ainakin teoriassa smithiläisen vapaan markkinatalouden periaatteiden nojalla). Yliopistojen tuotteiden kysyntä määräytyy sen mukaan, mitä valtio ja välittömämmin mitä opetus- ja kulttuuriministeriö haluaa, ja ministeriön preferenssinä ei ole laatu vaan määrä. Yliopistoja ohjataan määrällisesti, ja tämä tässä ohjausjärjestelmäksi kutsutussa palkitsemis- ja rankaisujärjestelmässä on kaikkein ongelmallisinta.

Tässä suhteessa vertailukohtaa ei tule hakea markkinatalouksissa toimivista yrityksistä, vaan se löytyy pikemminkin vanhasta kunnon Neuvostoliitosta. Neuvostoliitossa yritysten tuotantoa johdettiin tunnetusti valtiojohtoisesti. Kulutustarvikkeiden tuotanto ei määräytynyt kysynnän mukaan vaan keskusjohtoisesti annettujen tuotantotavoitteiden mukaan. Toki keskusjohdossa varmastikin mietittiin, mitä yhteiskunnassa tarvitaan tai mitä yksittäiset ihmiset tarvitsevat. Tämä tarvearviointi ei aina kuitenkaan osunut yksiin todellisen tarpeen kanssa - ja sama ongelma vaivaa tietenkin jokaista kysynnän monopolia.

Valtiokeskeinen tarpeen arvioiminen on erittäin vaikeaa: tehdas saattaa tuottaa jotakin, mitä kukaan ei tarvitse tai halua. Toisaalta tehdas saattaa tuottaa hyvinkin jotakin sellaista, mitä tarvitaan, mutta koska tehdas ei toimi tuotteiden kysynnän mukaan vaan tuotantotavoitteiden mukaan, se ei tuota sitä, mitä todella tarvitaan vaan sitä, mitä valtiojohto vaatii.

Niinpä kun naulatehtaan palkitsemisjärjestelmää muutettiin niin, että on tuotettava mahdollisimman paljon nauloja, tehdas alkoi tuottaa puolen sentin nauloja. Nauloja kyllä tarvittiin, mutta ei noin pieniä. Kukaan ei tehnyt niillä mitään. Kun valtiojohto sitten muutti tavoitteita niin, että on tuotettava mahdollisimman kestäviä nauloja, tehtaanjohto päätti tuottaa tonneja painavia nauloja ja niin edelleen.

Voidaan tietenkin sanoa, että tehtaanjohto oli vastuuton eikä tehnyt, mitä oikeasti olisi pitänyt tehdä. Toisaalta voidaan sanoa, että se mitä parhaimmalla tavalla mukautui vallitsevaan ohjausjärjestelmään. Ohjausjärjestelmän näkökulmasta se oli mallitehdas. Sen sijaan, että sanottaisiin tehtaanjohdon olevan epämoraalinen oman hyödyn tavoittelija, kyse on pikemminkin siitä, että ohjausjärjestelmä itsessään tuottaa ei-toivottuja seurauksia. Se ei tee näin niinkään siksi, että sitä väärinkäytetään vaan siksi, että siihen mukaudutaan kirjaimellisesti.

Nähdäkseni juuri tämä on nykyisen yliopistojen ohjausjärjestelmän suurin ongelma. Valtion ohjausjärjestelmä asettaa yliopistot erittäin vaikean kysymyksen eteen: olisiko yliopistojen todellakin tuotettava opetus- ja kulttuuriministeriön vaatimia tuotoksia maksimaalisella tehokkuudella? Siis todella.

Yhtäältä näyttää siltä, että valtio haluaa tätä, mutta toisaalta on vaikea uskoa, että se haluaa tätä loppuun asti. Näin ollen valtio ohjaa yliopistot tekemään jotakin, mitä se itse asiassa ei edes halua. Samalla yliopistot joutuvat niin sanoaksemme alisuorittamaan, koska ne tietävät, että vain alisuorittaminen - alisuorittamalla suhteessa tuotantotavoitteisiin - legitimoi niiden olemassaolon. Ainoastaan tekemättä sitä, mitä ohjausjärjestelmä haluaa, yliopisto voi säilyä laitoksena, jolla on ymmärrettävä tarkoitus ja päämäärä.

Ajatellaan tarkemmin opetusta ja tutkimusta. Jos tavoitteena on tuottaa mahdollisimman paljon maistereita ja tohtoreita mahdollisimman nopeasti, niin miksi yliopistot eivät vain yksinkertaisesti laskisi tutkintovaatimuksiaan niin alas, että jo uusien opiskelijoiden tervetuliaisseremoniassa jaettaisiin saman tien tutkintodistukset? Ainakin tenttivaatimuksia voitaisiin reilusti laskea (miksi opiskelijan pitäisi tenttiä kolme kirjaa, eikö yksi artikkeli riittäisi) tai tähdätä siihen, että opinnoista suurin osa on itseopiskelua, jolloin opettamiseen ei tarvitsisi tuh- 
lata resursseja, sillä siihen käytetty aikahan on pois julkaisujen tuotannosta. Miksi tutkijat eivät vain tehtailisi artikkeleita mahdollisimman suurella vauhdilla ja muuttaisi aikaisemmin julkaisemiensa tekstien sisällöstä vain vaaditut $20 \%$, jotta ne kelpaisivat uusina artikkeleina uusiin julkaisuihin? Miksi lainkaan tutkia mitään uutta, sillä onhan helpompaa, nopeampaa ja tehokkaampaa toistaa vanhaa? Ja artikkeleita on joka tapauksessa paljon helpompikin saada julkaistuiksi, kun ei esitä mitään ennenkuulumatonta vaan vain muuntelee jo ajateltua ja sanottua. Miksi kouluttaa suomalaisia tohtoreita, kun ulkomaalaisista saa enemmän pisteitä? Valitaan tohtorikouluihin vain muunmaalaisia tohtoriopiskelijoita, suomalaiset menkööt muualle. Miksei matkusteltaisi jatkuvasti ulkomailla luennoimassa (tästäkin opetusministeriö tarjoaa rahaksi muutettavia pisteitä)? Opetustahan ei tarvitsisi lainkaan järjestää, jos opiskelijat valmistuisivat välittömästi tai ainakin varsin lyhyessä ajassa. Miksei luvattaisi opiskelijalle hyvää arvosanaa sillä ehdolla, että hän antaa luennosta - jos sellaisia lainkaan järjestetään - vain hyvää palautetta (opiskelijapalaute tulee nimittäin muodostamaan $3 \%$ yliopistojen rahoituksesta)? Ja niin edelleen, loputtomiin.

Tietenkään yliopistot eivät halua tätä, eikä varmaan valtiokaan. Silti valtio on käynnistänyt ohjausjärjestelmän, jonka logiikka selvästikin johtaa tällaiseen toimintaan - nimittäin jos me uskomme tuohon järjestelmään tai otamme sen kirjaimellisesti. Aivan kuten Neuvostoliitossa, myös tässä täydellinen mukautuminen järjestelmään tekee toiminnasta järjetöntä.

Yliopistoissa tämä tiedetään, ja sama tiedetään varmasti myös opetusministeriössä, mutta silti ministeriön ohjausta jatketaan. Tämä on kyynistä kaksinaismoralismia: yhtäältä vaaditaan mukautumista ohjaukseen, toisaalta salassa kuitenkin halutaan, että tätä ensimmäistä vaatimusta ei täytetä kirjaimellisesti vaan vain siltä osin, että yliopistojen opetuksen ja tutkimuksen laatu paranee - mutta tähänhän yliopistolaiset ovat tähdänneet aina, aivan itsenäisesti.
Kuulun vielä siihen sukupolveen, jolle "autonomia" oli tuttu sana, "yliopiston autonomia", jopa "tutkimuksen autonomia" tai "professorin autonomia". Mitä on autonomia? Tunnetuin vastaus tähän kysymykseen löytyy varmastikin Immanuel Kantilta, tarkemmin sanoen hänen kirjoituksestaan "Mitä on Valistus?" Kantille autonomia on olemassaoloa ilman toisen ohjausta. Toisen ohjauksessa oleva ei ole autonominen eli itsenäinen eikä Kantin mielestä näin ollen täysi-ikäinenkään. Toisen ohjauksessa oleva ei ole itseohjautuva vaan alaikäinen, holhouksenalainen. Jo se, että on olemassakin jokin sellainen kuin ohjausjärjestelmä, tuhoaa yliopistojen autonomian.

Ohjausta on tietenkin monenlaista. On olemassa sielunohjausta, nuorisonohjausta, oppilaanohjausta, graduohjausta, väitöskirjanohjausta, liikenteenohjausta, autonkin ohjausta. Osa ohjauksesta on pakottamista (valitsemalla kytkimen ja kaasupolkimen painon pakotan auton menemään sinne, minne haluan), osa taas ohjeiden antamista ja neuvomista.

Yliopiston ohjaus ei muistuta mitään näistä. Yliopiston ohjaus ei ole pakottamista eikä neuvomista. Se on sellaisen toimintaympäristön luomista, joka palkitsee määrätystä toiminnasta ja rankaisee vuorostaan määrätynlaisesta palkinnon saamatta jäämisellä. Usein puhutaan kannustinjärjestelmistä, mutta tämä kuulostaa eufemismilta. Yliopistoja ohjataan samalla tavoin kuin rottia psykologian laboratoriossa: rotalle luodaan määrätynlainen keinotekoinen ympäristö, jossa tietystä toiminnasta saa palkinnon (esimerkiksi painamalla vihreää nappia), kun taas toisesta toiminnasta tulee rangaistus tai palkinnotta jääminen (esimerkiksi, kun rotta painaa punaista nappia). Pian rotta ehdollistuu painamaan vain vihreää nappia. Se alkaa toimia kannustinjärjestelmän mukaan ja mikä parasta, se tekee tämän ikään kuin vapaaehtoisesti. Eihän kukaan pakota eläintä tekemään mitään, vaan se vain mukautuu järjestelmään.

Tietyssä mielessä yliopistot on pantu laboratoriorotan asemaan. Yliopistouudistuksen jälkeen niiden liikkumavapaus lisääntyi, mutta 
samalla tuo vapaus merkitsi vain sen toiminnan vapaaehtoista valintaa, jota siltä valtiovallan puolelta edellytetään. Sen sijaan, että yliopistoja ja yliopistolaisia holhottaisiin, ne on ikään kuin tungettu laatikkoon, jossa ne voivat vapaasti ja yhä uudelleen valita sen vaihtoehdon, joka on niiden intressien mukainen tässä laatikossa eli ohjausjärjestelmän tuottamassa keinotekoisessa toimintaympäristössä.

On kuitenkin selvää, että kyse ei ole vain määrätyistä jo olemassa olevista subjekteista määrätyssä toimintaympäristöstä, sillä toimintaympäristöt luovat ja tuottavat subjekteja ja määrätynlaisia identiteettejä. Ihminen on pitkälti sitä, mitä hän lukee, näkee, kuulee ja haistaa. Jos häntä palkitaan määrätystä toiminnasta ja rangaistaan toisesta, hän alkaa nähdä itsensäkin tässä valossa: hyvänä ihmisenä ja työntekijänä jos saa palkintoja, huonona jos ei niitä saa.

Kun yliopiston ohjausjärjestelmä ulotetaan laitos- ja henkilötasolle (ei ainoastaan yliopistoja vaan henkilökuntaakin arvioidaan heidän keräämiensä pisteiden perusteella), ryhdytään muovaamaan aivan uudenlaisia opettaja- ja tutkijasukupolvia. Nämä uudet sukupolvet eivät enää välttämättä tiedä mitään opetuksen ja tutkimuksen todellisista laatukriteereistä (tai jos tietävätkin, ne eivät niistä välitä), vaan ottavat ohjausjärjestelmän kannustimien asettamat kriteerit annettuna, ilman etäisyyttä uskoen, että ne todellakin mittaavat opetuksen ja tutkimuksen ja lopulta tutkijoiden ja opettajien itsensä hyvyyttä ja huonoutta.

Tällöin ollaan vaarallisilla vesillä. Jos tämä ohjausjärjestelmän luoma uusi toimintaympäristö todellakin tuottaa tällaisia subjekteja nimittäin subjekteja, jotka toimivat täysin sen ehdoilla - silloin voidaan sanoa hyvästit koko yliopistolaitokselle. Nämä subjektit ovat järjestelmän uhreja, mutta lopulta järjestelmästä, joka heidät synnytti, tulee näiden uhrien uhreja. Ei ainoastaan absurdius vaan koko yliopistolaitoksen loppu on kirjoitettu yliopistojen ohjausjärjestelmän ytimeen.

Tilanne ei toki ole vielä näin synkkä. Nykyisin me voimme vielä ikään kuin käyttää yliopistojen ohjausjärjestelmää tavalla, joka tuottaa hyviä tuloksia jopa opetuksen ja tieteen kannalta. Me pystymme - vaikka tosin vain vaivoin - tehostamaan opetusta heikentämättä sen laatua ja lisäämään julkaisujen määriä vähentämättä niiden todellista tieteellistä tai tutkimuksellista arvoa, mutta me pystymme tähän ainoastaan siksi, että tiedämme, että opetuksella ja tutkimukselle on olemassa myös todelliset laatukriteerinsä, jotka ovat kokonaan ohjausjärjestelmästä riippumattomat.

Myös meidän jälkeemme tuleva sukupolvi pystyy tähän - yksinkertaisesti siksi, että me kerromme nuo kriteerit heille - mutta mitään takeita tästä ei ole. Entä jos tulee sukupolvi, joka ei joko anna niille enää mitään arvoa tai edes tiedä niistä mitään vaan uskoo yliopistojen erinomaisuuden perustuvan todellakin sille, miten monta pistettä yliopistot saavat ohjausjärjestelmän pistelaskusysteemissä? Tämä on kauhuskenaario, mutta se ei ole pessimistin skenaario vaan skenaario, joka on sisäänkirjoitettu yliopistojen nykyiseen ohjausjärjestelmään.

Miten sitten yliopistoja tulisi ohjata? Koulutuspoliittiset näkökohdat ovat aina poliittisia, ja siksi on selvää, että yliopistot eivät voi olla mitään ulkopuolisesta maailmasta erillään olevia saarekkeita. Ollakseen tehokasta ja laadukasta yliopistojen tutkimustoiminnan tulee kuitenkin olla itseohjautuvaa. Jos yliopistojen toiminta mukautuu markkinoiden tai poliittisen johdon vaatimuksiin, sen varsinainen toiminta - vapaa tieteellinen tutkimus ja tutkimusperusteinen korkein opetus - automaattisesti kärsii. Tämä ei tietenkään tarkoita, että yksittäiset yliopistot voisivat levätä laakereillaan. Aivan kuten yritysten, yliopistojenkin on kilpailtava, mutta sen sijaan, että ne kilpailisivat kysynnän markkinoilla, ne kilpailevat tieteellisen laadun markkinoilla. Rahan sijaan näitä markkinoita ohjaa tahto tietoon ja totuuteen. Vasta kun tämä ymmärretään, voivat yliopistot olla myös taloudellisesti ja yhteiskunnallisesti hyödyllisiä.

— MIKA OJAKANGAS 